\title{
PEMANFAATAN TEKNOLOGI KOMUNIKASI DAN INFORMASI DALAM PENGEMBANGAN DAKWAH
}

\author{
Oleh :M.Ishaq Shamad \\ Dosen Fakultas Agama Islam Universitas Muslim Indonesia \\ UMI Makassar \\ Email :ishaq5samad@yahoo.com
}

\begin{abstract}
Tulisan ini menyajikan beberapa aspek penting kaitan antara teknologi komunikasi dan informasi dengan peningkatan dan pengembangan dakwah, termasuk dakwah melaui pendidikan. Dalam kehidupan manusia di era global saat ini, manusia selalu berhubungan dengan teknologi, yang pada hakikatnya adalah alat untuk mendapatkan nilai tambah dalam menghasilkan produk yang bermanfaat. Teknologi sekarang ini perkembangannya sudah sangat pesat. Situasi masyarakat membawa kepada keadaan yang sejalan dengan kecenderungan global yang ditandai dengan era informasi, era keterbukaan, era demokratisasi, deregulasi dan desentraralisasi. Namun demikian euphoria kebebasan dan perubahan ini jangan sampai membawa bangsa tenggelam di dalam perubahan-perubahan yang amat cepat, tetapi bagaimana sebagai individu dan kelompok baik pada tingkat lokal, nasional maupun global memposisikan diri dalam menghadapi gejolak perubahan tersebut.
\end{abstract}

\section{Pendahuluan}

Keywords :

Teknologi, Informasi, Komunikasi, Dakwah

Perkembangan dalam Teknologi Informasi dan Komunikasi (TIK) telah memberikan dampak yang sangat signifikan ke semua aspek kehidupan manusia. Perkembangan ini memiliki dampak semakin terbuka dan tersebarnya informasi dan pengetahuan dari dan ke seluruh dunia menembus batas, jarak, tempat, ruang dan waktu. Pengaruhnya pun meluas keberbagai kehidupan, termasuk bidang pendidikan. Pendidikan merupakan suatu proses yang tujuannya untuk meningkatkan nilai social, budaya, moral dan agama serta mempersiapkan peserta belajar menghadapi tantangan dan pengalaman dalam kehidupan nyata. Untuk itu dalam pendidikan diperlukan proses pembelajaran yang efektif dan efisien yang menjadikan peserta belajar dapat menyerap informasi dan pengetahuan serta teknologi yang dipelajarinya sebagai bagian dari dirinya (Isniatun Munawaroh, 2017). 
Dalam kehidupan manusia di era global saat ini, manusia akan selalu berhubungan dengan teknologi. Teknologi menurut Smaldino (2008:12) pada hakikatnya adalah alat untuk mendapatkan nilai tambah dalam menghasilkan produk yang bermanfaat. Teknologi sekarang ini perkembangannya sudah sangat pesat. Alvin Toffler dalam Munir (2011:29) menggambarkan perkembangan tersebut sebagai sebuah revolusi yang berlangsung dalam tiga gelombang yaitu, gelombang pertama dengan munculnya teknologi dalam pertanian, gelombang kedua munculnya teknologi industry dan gelombang tiga munculnya teknologi informasi yang mendorong tumbuhnya komunikasi. Ketiga perkembangan tersebut telah berhasil menguasai dan mempengaruhi kehidupan manusia di dunia. Sehingga jika "gagap" teknologi maka akan dapat tertinggal untuk memperoleh kesempatan untuk meju. Informasi dan telekomunikasi telah memiliki peran yang amat sangat penting dan nyata, apalagi masyarakat saat ini sedang menuju kepada masyarakat ilmu pengetahuan.

Gejolak perubahan yang penuh dengan ketidakpastian itu membawa kita semua kepada upaya memilih dan menetapkan alternatif-alternatif yang paling baik bagi setiap orang. Dalam menghadapi perubahan yang cepat tersebut satu-satunya cara untuk tetap dapat berada pada posisi yang baik dalam situasi perubahan yang begitu cepat dan hampir-hampir tak terkendalikan itu adalah "belajar secara cepat" pada semua bidang kehidupan tak terkecuali bidang dakwah.

Kecepatan perubahan yang diistilahkan dengan "accellerated change”, 'tumultuous change." "rapid change" para ahli menuntut agar semua yang hidup dalam abad informasi, era globalisasi yang diwarnai oleh revolusi teknologi komunikasi dan informasi mendorong setiap individu, lembaga dan organisisasi serta institusi pendidikan untuk melakukan repositioning agar senantiasa dapat exist dalam era yang penuh dengan "uncertainty", “continuity” dan "confrontation” yang jika tidak dihadapi dengan penuh kearifan, kesiapan dan "kecerdasan" akan membawa malapetaka yang akan sulit mengatasinya.

Untuk itu diperlukan alat yang tepat dan manajemen yang baik agar keberadaan kita dalam situasi itu selain dapat mengikuti juga sekaligus diharapkan dapat mempengaruhi dan mengarahkan perubahan itu. Kemampuan itu hanya dapat dimiliki dengan memahami sebaik- 
baiknya perilaku dan sifat teknologi komunikasi dan informasi agar dapat dimaksimalkan pemanfaataannya bagi berbagai kepentingan dan khususnya di bidang dakwah.

Kesemua itu hanya mungkin dilakukan selain dengan memahami perilaku dan sifat teknologi komunikasi dan informasi juga harus dipahami dengan sebaik-baiknya kaitan yang kuat antara teknologi komunikasi informasi dengan dakwah.Peranan teknologi informasi dapat dimaksimalkan dengan mengkaji kemungkinan-kemungkinan yang dapat dilakukan untuk dakwah dengan memanfaatkannya secara maksimal.Perannya dalam berbagai segi kehidupan umumnya telah banyak dikenal atau bahkan telah digunakan oleh berbagai kalangan tidak terkecuali dalam bidang dakwah.

\section{Pembahasan}

Meurut Arif Kusuman (http://www.esaunggul.ac.id/), teknologi informasi dapat dikatakan sebagai ilmu yang diperlukan untuk mengelola informasi agar informasi tersebut dapat dicari dengan mudah dan akurat. Isi dari ilmu tersebut dapat berupa teknik-teknik dan prosedur untuk menyimpan informasi secara efisien dan efektif. Informasi dapat dikatakan sebagai data yang telah terolah. Informasi ini dapat berupa ramalan cuaca, surat, berita, publikasi hasil penelitian dan pengembangan atau program pendidikan atau latihan, misalnya teknik mengelas, cara memasak, pelajaran musik atau pelajaran lain. Informasi tersebut dapat disimpan dalam bentuk tulisan, suara, gambar mati ataupun gambar hidup. Sehingga informasi akhirnya dapat berupa ilmu dan pengetahuan itu sendiri.

Bila informasi tersebut volumenya kecil, tentunya tidak diperlukan teknik-teknik atau prosedur yang rumit untuk menyimpannya. Namun bila informasi tersebut dalam volume yang besar, diperlukan teknik dan prosedure tertentu untuk menyimpannya agar mudah mencari informasi yang tersimpan. Komputer mempunyai kapasitas untuk menyimpan informasi dalam volume besar. Pada mulanya, komputer hanya mampu menyimpan teks dan grafik sederhana saja. Namun dewasa ini, komputer telah mampu menyimpan informasi dalam berbagai bentuk, misalnya dalam bentuk suara, gambar mati, gambar hidup, bahkan gabungan gambar hidup dan suara dalam bentuk film. Namun ada juga informasi yang belum mampu disimpan oleh komputer, yaitu antara lain informasi mengenai bau, dan rasa. 
Bayangkan bila informasi seperti bau dan rasa ini dapat disimpan dalam komputer, maka pada program latihan memasak nasi goreng yang ditayangkan lewat televisi atau sebagai paket program komputer, selain suara dan proses pemasakannya yang bisa disaksikan, bau dan rasanya pun dapat dirasakan.

Dalam suatu institusi, ada informasi yang perlu dikomunikasikan dari satu bagian ke bagian yang lain. Cara yang paling sederhana untuk mengkomunikasikan informasi adalah dengan memindahkan informasi tersebut ke tempat lain. Namun bila ada jarak antara pengirim dan penerima informasi, maka proses penyampaian itu akan bermasalah. Dalam situasi dimana jumlah pihak yang memerlukan informasi itu banyak dan informasi yang diperlukan bervariasi, proses penyampaian informasi tersebut menjadi lebih rumit. Kehadiran kombinasi teknologi komputer, teknologi informasi dan teknologi komunikasi/telekomunikasi sangat mempermudah penyampaian informasi dalam bentuk yang telah diidentifikasi di atas.

Percepatan dalam perubahan harus diimbangi dengan kecepatan dalam belajar sebab milenium III lebih diwarnai oleh perubahan kecenderungan yang amat kuat dari mengajar kepada belajar sebagaimana telah dikemukakan oleh Rose dan Nicholl (1997) di mana manpower telah digantikan perannya oleh mindpower/brainpower/intellectual power sebab perubahan-perubahan yang cepat termasuk apa yang disebut revolusi teknologi komunikasi dan informasi ditandai dengan perubahan yang cepat (accellerated change) dan untuk itu perlu diimbangi dengan kecepatan di dalam belajar (accellerated learning).

Kecepatan didalam belajar dapat dilakukan antara lain dengan memperhatikan prinsip-prinsip berikut :

1. Belajar bagaimana belajar (learning how to learn);

2. Memahami dengan baik teknik belajar sendiri (natural learning style);

3. Memiliki kemampuan/ keterampilan dalam memanfaatkan teknologi informasi dalam berdakwah;

4. Mengkaji informasi dengan cepat, memahaminya dan diingat dengan baik.

Mengkaji dan mengimplementasikan prinsip-prinsip di atas diharapkan dapat membantu percepatan dalam belajar yang juga sekaligus merupakan tuntutan era informasi 
yang dipacu lebih cepat melalui revolusi teknologi komunikasi dan informasi sebagaimana telah diutarakan.

Memanfaatkan berbagai kemudahan dari teknologi komunikasi dan informasi hanya mungkin terjadi jika dikelola dengan baik. Oleh karena sifat yang melekat pada teknologi komunikasi dan informasi, membuka kemungkinan bagi pemanfaatannya secara luas dalam bidang dakwah baik pada tingkat perencanaan dan pembuatan keputusan (decision support system) tentang suatu kebijakan sampai pada implementasinya dalam mendukung proses pengembangan dakwah tersebut. Hal itu dimungkinkan oleh besarnya peluang untuk mengakses informasi secara cepat dalam waktu singkat dan dari sumber-sumber informasi yang bervariasi dengan tingkat akurasi yang tinggi.

Teknologi Informasi Arif Kusuman (http://www.esaunggul.ac.id/) merupakan suatu istilah yang menunjukkan berbagai macam hal dan kemampuan yang digunakan dalam pembentukan, penyimpanan, dan penyebaran informasi, selain itu Teknologi Informasi mencakup: komputer, jaringan komunikasi, konsumen elektronik, "know-how". Di dalam era globalisasi tampaknya teknologi informasi selayaknya memperoleh tempat guna mendukung proses belajar mengajar yang ada di Indonesia, yang tentunya harus didukung infrastruktur yang ada guna mendukung pemanfaatan teknologi informasi, pengembangan materi pengajaran dan strategi yang akan diterapkan.

Pemanfaatan Teknologi Informasi untuk Pendidikan dan Pelatihan Teknologi informasi yang telah diterap kan dapat dikategorikan menjadi tiga kelompok. Kelompok yang pertama adalah memanfaatkan komputer untuk menyampaikan materi pengajaran itu sendiri, yang biasa dikenal dengan istilah Computer Assisted Instructional (CAI) atau Computer-Based Training (CBT). Pada pemanfaatan jenis ini, informasi (materi belajar) yang hendak disampaikan kepada peserta ajar dikemas dalam suatu perangkat lunak. Peserta ajar kemudian dapat belajar dengan cara menjalankan program atau perangkat lunak tersebut di komputer. Bila dirancang dengan baik, dapat diciptakan paket program belajar sehingga peserta dapat melakukan simulasi, atau juga dapat memberikan umpan balik kepada peserta ajar kemajuan belajarnya.

Pemakaian kelompok kedua adalah untuk pendistribusian materi ajar melalui jaringan Internet. Materi ajar dapat dikemas dalam bentuk webpage, ataupun program belajar interatif 
(CAI atau CBT). Materi ajar ini kemudian ditempatkan di sebuah server yang tersambung ke Internet sehingga dapat diambil oleh peserta ajar baik dengan memakai Web-Browser ataupun File Transport Protocol (aplikasi pengiriman file).

Era digitalisasi (idcloudhost.com) tentunya menjadi peluang yang sangat bagus untuk banyak sektor. Peluang disini tidak hanya bicara mengenai perkembangan ataupun lebih mengarah ke modernisasi belaka. Tapi dengan adanya digitalisasi tentunya bisa memberikan kita banyak manfaat untuk mempermudah pekerjaan. Hal ini bisa kita katakan digitalisasi di dunia pendidikan sendiri menjadi peran penting untuk menunjang proses belajar mengajar di sekolah dan dimanapun kita berada. Dalam proses pembelajaran, dengan adanya digitalisasi tentunya mengajarkan semua pihak yang terlibat dapat dengan mudah untuk belajar. Menggunakan teknologi tentunya akan mempermudah mahasiswa berinteraksi dengan guru. Hal ini bisa dari segi komunikasi hingga ke proses bagaimana sistem pendidikan layak digunakan dengan teknologi informasi.

Mahasiswa akan lebih semakin kitis mengenal teknologi sejak dini, hal ini yang menyebabkan perlu adanya pertimbangan guru saat mengajar. Ada banyak metode yang sering digunakan sekolah untuk bisa memanfaakan teknologi informasi mulaid dari bentuk teks, gambar, dan video. Tentunya konten-konten edukatif tersebut akan lebih menarik minat belajar disekolah. Salah satu contoh adalah penggunaan Google apps for Education yang bisa berkolaborasi, realtime, dan mempermudah proses belajar mengajar secara offline maupun online.

Pemanfaatan kelompok ketiga adalah sebagai media komunikasi dengan pakar, atau nara sumber, atau peserta ajar lain. Komunikasi ini dapat digunakan untuk menanyakan halhal yang tidak bisa dimengerti, atau mengemukakan pendapat supaya dapat ditanggapi oleh peserta yang lain. Dengan demikian peserta ajar bisa mendapat umpan balik baik dari pakar atau nara sumber serta dari teman peserta didik yang lain mengenai hal-hal yang berkaitan dengan pemahaman materi ajar.

Kesempatan seperti itu hanya mungkin diatasi dengan pemanfaatan teknologi komunikasi dan informasi secara baik. Revolusi informasi global telah berhasil menyatukan kemampuan komputasi, televisi, radio dan telefoni secara terintegrasi Hal ini juga merupakan 
hasil dari suatu kombinasi revolusi dibidang komputer personal, transmisi data dan kompresi, lebar pita (bandwidth), teknologi penyimpanan data (data storage) dan penyampai data (access) integrasi multimedia dan jaringan komputer. Konvergensi dari revolusi teknologi tersebut telah menyatukan berbagai media, yaitu suara (voice,audio), video, citra (image) grafik dan teks. (Adisasono, 2000)

Teknologi komunikasi dan informasi pada dasarnya memungkinkan dan memudahkan manusia untuk dapat saling berhubungan dengan cepat, mudah dan terjangkau serta memiliki potensi untuk membangun masyarakat yang demokratis.

Dengan sifat-sifat teknologi komunikasi dan infromasi seperti itu telah membuka peluang besar bagi pemerintah daerah dan kota untuk dapat menyiapkan diri membangun sebuah sistem informasi yang memungkinkan terjadinya proses pemanfaatan teknologi komunikasi dan informasi bagi kemajuan dakwah di daerah dan kota. Itu juga berarti bahwa melalui pemanfaatan teknologi komunikasi dan informasi tersebut khususnya internet kendala keterjangkauan dan ekspose terhadap informasi antar berbagai wilayah di seluruh Indonesia dapat diatasi dan keutuhan wilayah negara kesatuan Republik Indonesia dapat tetap terjaga.

Namun yang terpenting dari keadaan ini adalah dibutuhkannya tanggung jawab moral setiap penyedia (provider) dan pengguna teknologi komunikasi dan informasi tersebut karena selain diperoleh kemudahan juga akan berjalan seiring dengan dampak negatif yang akan ditimbulkannya seaindainya pemanfaatannya itu tidak didasari "nilai-nilai keimanan dan ketaqwaan, etika, estetika dan kearifan para pemakainya”.

Hanya dengan mengembangkan nilai-nilai seperti itu dampak negatif dari pemanfaatan teknologi komunikasi dan informasi khususnya internet dapat diminimalkan terutama bagi generasi muda yang masih dalam pertumbuhan dan pancaroba.

Membangun sebuah keterbatasan dalam bersentuhan dengan teknologi komunikasi dan informasi tersebut hampir tidak mungkin karena begitu terbukanya berbagai sumber informasi yang disana sini diwarnai dengan berbagai "trick" yang mengundang keterlibatan semua orang termasuk generasi muda untuk terlibat kedalam sistem teknologi komunikasi dan informasi yang "mereka" bangun. 
Hal itu amat dimungkinkan karena dengan arahan yang tepat dan sedikit intervensi, teknologi komunikasi dan informasi dapat membantu mentransformasikan mereka yang selama ini berada pada posisi marjinal di banyak daerah dengan peralatan sebuah komputer multi media dapat berubah dari posisi pengamat menjadi menjadi posisi partisipan aktif, dan disinilah sebenarnya peranan teknologi informasi terhadap dunia dakwah dalam proses demokratisasi menjadi sangat signifikan.

Dengan berkembangnya teknologi informasi tersebut batas-batas antar negara menjadi hilang (borderless nations) demikian pula antara binis, dakwah dan bahkan media.Perkembangannya begitu dahsyat sehingga hampir tidak ada aspek kehidupan (pendidikan dan dakwah, perdagangan, semua segi usaha, hiburan, pemerintahan, pola kerja, pola produksi dan bahkan pola hubungan antar manusia) yang terlepas dari pengaruh atau bahkan dampak yang ditimbulkannya yang pada saat sekarang ini menjadi perhatian serius dari berbagai negara di dunia.Apa yang pada mulanya sulit dicapai oleh daerah khususnya daera-daerah yang terpencil hampir dapat dipastikan tidak ada kendala lagi sepanjang perangkat teknologi yang butuhkan memang tersedia.

Menjelang memasuki abad ke-21 hampir semua negara di dunia bertanya tentang masa depan dunia yang mengalami perubahan dengan cepat itu. Untuk memahami persoalan itu dengan baik sejumlah ahli di bidang bisnis, organisasi dan manajemen serta keuangan dunia menuangkan kembali pemikiran mereka melalui sebuah buku yang berjudul "Rethinking the Future" sebuah buku yang menjelaskan perkembangan dunia yang ditandai dengan ketidakpastian uncertainty yang semakin meningkat dalam mana pekerjaan, organisasi dan ekonomi juga turut berubah.

Guna mengantisipasi semua itu berbagai negara maju didunia telah siap dengan program-program dan proyek mereka khususnya dalam bidang pendidikan untuk dapat memasuki abad ke-21 tersebut sebagai abad informasi dapat dimasuki dengan mulus.Dalam upaya-upaya itu sistem-sistem yang sentralistik sudah mulai ditinggalkan dan mulai mengarah pada desentralisasi kekuasaan dan wewenang dalam berbagai bidang kehidupan.

Antisipasi terhadap hal ini diantaranya telah dilakukan oleh Amerika dengan berbagai proyek pemanfaatan teknologi dalam bidang pendidikan dan keterkaitannya dengan peran dunia bisnis dan industri. 
Sebagai negara industri maju Amerika Serikat dalam upaya menempatkan posisi pendidikan terhadap kemajuan teknologi dan revolusi teknologi informasi mengetengahkan beberapa pertanyaan: "In highly advanced, technological society such as the United States, how do students know what skills they need to qualify for the jobs, and the advanced training of their choice? How can schools best teach necessary skills? How can industry and educational together help create a more effective education system, a more vibrant, productive economy?"

Dalam menjawab pertanyaan-pertanyaan tersebut tidak kurang dari mantan Presiden Amerika Serikat Bill Clinton telah menggagas sebuah agenda nasional untuk pendidikan yang diberi nama “The President's Educational Technology Initiatives". Untuk merealisasikan gagasannya itu mantan Presiden mengemukakan bahwa "In our schools, every classroom in America must be connected to the information superhighway, with computers and good software, and well-trained teachers. We are working with the telecomunications industry, education and parents to connect 20 percent of California's classrooms this spring, and every clasroom and every library in the entire United States by the year 2000. I ask congress to support this educational technology initiative so that we can make sure this national partnership succeeds."

Apa yang dikemukakan dalam pandangan di atas merupakan fokus dari dari tulisan ini. Persoalannya sekarang adalah bagaimana agar dengan segala kemampuannya dan kendala yang dihadapinya masjid dan media dakwah dapat membangun sebuah model jaringan antar masjid dan antar lembaga keagamaan di daerah untuk saling berhubungan sehingga informasi penting dan kemajuan-kemajuan dalam bidang dakwah di suatu daerah dapat diakses.

Hal itu tentunya dapat diatasi seperti yang telah dikemukakan dalam sebuah tulisan yang berjudul "Innovation in 21st Century Education" dikatakan sebagai berikut :" With the internet, we have a chance to change that! First we can expand the scope of social issues, as well as coming up with new perspectives by teaching HTML, the language of the net in social science classes, and require them to write a webpage. HTML is basically a word processing and easy to learn, no other language is needed for non-business uses.I've written 15 pages, 
all without using any other language, except stuff I've cut and pasted and not needed to modify."

Untuk mencapai apa yang dikemukakan diatas dapat diperoleh melalui sebuah jaringan KOMPUTER terbesar di dunia yang disebut dengan INTERNET, yang dapat berfungsi dengan baik jika didukung oleh perangkat komputer dengan perangkat lunak yang baik, dan dengan guru yang terlatih baik. Menggunakan internet dengan segala fasilitasnya akan memberikan kemudahan untuk mengakses berbagai informasi untuk pendidikan yang secara langsung dapat meningkatkan pengetahuan mahasiswa bagi keberhasilannya dalam belajar. Melalui teknologi informasi yang dimiliki baik oleh daerah maupun oleh individual, dapat memanfaatkannya diantaranya untuk :

1. Penelusuran dan pencarian bahan pustaka;

2. Membangun Program Artificial Intelligence (kecerdasan buatan) untuk memodelkan sebuah rencana pengajaran;

3. Memberi kemudahan untuk mengakses apa yang disebut dengan virtual clasroom ataupun virtual university;

4. Pemasaran dan promosi hasil karya penelitian;

Kegunaan-kegunaan seperti diatas itu dapat diperluas bergantung kepada peralatan komputer yang dimiliki jaringan dan fasilitas telepon yang tersedia dan provider yang bertanggung jawab untuk tetap terpeliharanya penggunaan jaringan komunikasi dan informasi tersebut. Dari waktu ke waktu jika dilihat dari jumlah pemakaian yang makin meningkat secara eksponensial setiap tahunnya memungkinkan fasilitas yang pada mulanya hanya dapat dinikmati segelintir orang, dan sekelompok kecil orang dengan biaya operasional yang tinggi, ke depan besar kemungkinan biaya yang besar itu akan dapat ditekan sehingga pemanfaatannya benar-benar dapat menjadi penunjang utama bagi pengelolaan pendidikan.

Agar pemanfaatan teknologi informasi tersebut dapat memberikan hasil yang maksimal maka juga dibutuhkan kemampuan pengelola teknologi komunikasi dan informasi yang baik dan dapat diperoleh melalui pelatihan baik untuk tingkat pembuat kebijakan di daerah maupun pada tingkat nasional. Mintzberg misalnya mengemukan sepuluh peran manajerial pemimpin yang beberapa di antaranya yaitu : 
1) informational roles menempatkan manager sebagai monitor, disseminator dan spokes person,

2) decisional roles yang melibatkan manager sebagai entrepreneur, disturbance handler, allocator dan negotiator,

3) interpersomal roles melibatkan manager sebagai figurhead, liason dan leader.

Melihat pada volume informasi yang diperlukan dan dihubungkan dengan keterbatasan teknologi yang dimilki lembaga dakwah untuk mengelola informasi menyebabkan sedikit sekali terjadi perubahan di masyarakat. Keadaan sekarang juga kadang bergantung pada informasi yang dimiliki seseorang di dalam kepalanya yang tidak selalu mudah untuk mengaksesnya., karena itu pada umumnya nampak bahwa lembaga dakwah, termasuk masuk pengelola masjid tidak selalu dapat mengawasi dan memanfaatkan dengan baik penyimpanan informasi di masjid. Selain itu, pemanfaatan website yang digunakan oleh sekolah dapat membantu proses administratif dengan cepat. Seperti contoh yang bisa kita ketahui bisa dimanfaatkan untuk menggunakan sistem absen yang menggunakan digital. hal ini tentunya akan membantu sekolah agar proses lebih cepat, laporan lebih cepat, hingga menghasilkan kesimpulan yang lebih cepat nantinya. Proses administrasi dengan menggunakna teknologi juga terbilang sangat bagus, dari Google for Education menyediakan email sekolah unlimited, hingga penyimpanan unlimited untuk pengguna sekolah sehingga akan mempermudah proses administrasi tanpa harus menggunakan banyak kertas sekaligus. IDcloudHost melalui program Ekabima memberikan fasilitas Wesbsite dan Google for Education GRATIS untuk seluruh sekolah yang ada di Indonesia. Program ini sudah diikuti oleh lebih 300 sekolah di Indonesia. Program ini gratis dan sekolah bisa mendaftar pada link berikut : https://idcloudhost.com/ekabima/

Di negara-negara yang sudah maju dalam bidang teknologi komunikasi dan informasi, peran penting dari komputer dalam pengelolaan pendidikan telah dikenal sejak kurang dari dua dekade yang lalu seperti dikemukakan oleh Commonwealth Schools Commission in 1984 Australia misalnya yang menyediakan program komputer bagi pendidikan melalui National Computer Education Program menyatakan bahwa : “...it was argued that principals and inschool administrators should use computing systems to enchance communications between 
all groups involved in the functioning of the school, and to streemline administration and curriculum support."

Peran pendidikan di setiap suatu negara sangat diutamakan, apa jadinya jika suatu negara tanpa pendidikan? Tetapi itu hal yang mustahil jika suatu negara buta akan pendidikan dan apalagi mereka menginginkaan negara mereka berkembang, Oleh karena itu seiring berjalannya waktu dalam dunia pendidikan teknologi informasi dan komunikasi sehingga tidak bisa kita hindari apalagi bagi siswa yang masih menjadi pelajar karena kita dituntut untuk mengikuti perkembangan tersebut supaya kita tidak ketinggalan akan perkembangan teknologi. Seperti yang dilakukan oleh para guru yang berada di sekolah SMK PGRI Tanjung

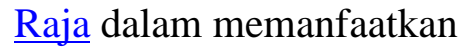

Teknologi Infomasi dan Komunikasi mereka memanfaatkan teknologi yakni komputer untuk dijadikan salah satu mata pelajaran produktif yaitu Teknik Komputer dan Jaringan karena siswa dituntut untuk memiliki keahlian di bidang komputer dan jaringan karena dengan cara ini lebih evisien untuk mengasa kemampuan para peserta didik/siswa. tidak hanya sebatas siswa yang memanfaatkan teknologi yang ada di sekolah tetapi para guru beserta para staf nya juga bisa memanfaatkannya, dalam hal pembuatan surat, laporan, dan apalagi disaat penerimaan siswa baru dalam memudahkan pendataan mereka lebih menggunakan komputer di bandingkan dengan kertas karena lebih memudahkan dalam penataan data siswa dan juga penghematan waktu dan tenaga. Dalam pemanfaatan Teknologi Informasi dan Komunikasi disekolah, kami memanfaatkan komputer menjadi bahan praktik prakitan, perbaikan, ataupun pemasangan program/os dan ada juga pembuatan server ataupun router, biasanya kami lakukan ketika kami akan belajar produktif TKJ (Teknik Komputer \& Jaringan) di dalam ruang Multimedia, bukan hanya sekedar bahan peraktik saja terkadang kami juga memanfaatkan komputer sebagai alat untuk membantu kami ketika akan membuat tugas sekolah. Selain itu kami juga sering datang di ICT Center Oi (Pusat TIK SMK Tra) untuk mencari info, berdiskusi ataupun bertanya pada yang ahlinya berkaitan dengan Teknologi Informasi dan Komunikasi yang sedang berkembang saat ini. ketika ingin mengirim e-mail, atau mencari tutorial yang kami butuhkan kami menggunakan jaringan internet yang ada disekolah untuk membantu kami menyelesaikan tugas atau belajar secara online E-Learning. 
Pembelajaran tidak hanya terjadi di dalam kelas, tetapi juga di luar kelas, seperti extrakulikuler yang diadakan setiap jam pulang sekolah yang memuat praktik menggunakan program pengolah kata, dengan cara seperti itu cukup efektif untuk mengembangkan keahliaan mereka dibidang komputer, bukan hanya siswa yang terbantu adanya teknologi komputer tetapi para guru pada saat menerangkan atau mengajar mereka sering menggunakan proyektor untuk memudahkan menjelaskan materi yang akan diajarkan.

Dalam mengembangkan teknologi di dalam lingkungan sekolah digunakan Sistem Operasi berbasis Open Source karena sistem operasi ini mudah digunakan dan free memungkinkan para siswa untuk menggunakannya tanpa harus membeli sistem operasi berbayar yang harganya tidak sedikit. Salah satu upaya dalam menggali potensi siswa dalam hal keahlian Teknik Komputer \& Jaringan, pihak sekolah bekerja sama dengan Kementerian Pendidikan dan Kebudayaan DIRJEN Pendidikan Menengah Direktorat Pembinaan SMK dan sekolah SMK lainnya untuk mengadakan lomba atau Latihan Keterampilan Siswa (LKS) tingkat kabupaten. (feridi.blog.upi.edu/2015).

Pengadaan perangkat komputer dan pengetahuan pemanfaatannya sudah merupakan sesuatu yang harus terutama dalam memasuki abad ke 21 dan dalam rangka mempersiapkan diri menerimanya sebab paling tidak karena beberapa hal:

1. Informasi yang disimpan secara elektronik memiliki fleksibilitas dalam mengkakses dan dalam pemanfaatannya yang sudah tidak mungkin dilakukan melalui sistem penanganan informasi dengan cara lama. Komputer juga menyediakan begitu banyak kemudahan dalam mengelola informasi dalam arti menyimpan, mengambil kembali dan pemutahiran informasi.

2. Komputer juga merupakan alat yang memiliki kemampuan luar biasa dalam membantu memanfaatkan informasi itu dalam rangka pengambilan keputusan dan pemecahan masalahan secara kreatif. Kemampuan komputer juga untuk memanipulasi dan menyusun kembali informasi untuk kepentingan khusus pemakai menjadikannya menjadi alat yang efektif dalam tugas menganalisis dan menanfsirkan kecenderungan yang terjadi, pengujian hipotesisi dan identifikasi kecenderungan baru program-program pengembangan dakwah. 
3. Komputer sebagai alat untuk memproses informasi, dan memiliki tingkat aplikasi dalam setiap langkah proses manjemen - perencanaan, mengkomunikasikan,mengorganisasikan, pengawasan dan memotivasi pengembangan dakwah.

\section{Kesimpulan}

Dengan memperhatikan berbagai hal berkenaan dengan pemanfaatan teknologi komunikasi dan informasi untuk pengembangan dakwah membuka peluang yang sebaikbaiknya bagi setiap lembaga terkait dengan pelaksanaan dan pengelolaan dakwah untuk bekerjasama secara lebih baik dan lebih erat dalam memanfaatkan teknologi informasi dan komunikasi.

Pemanfaatan informasi dan teknologi juga digunakan dalam dunia pendidikan, sehingga memudahkan para pembelajar untuk bisa mengakses informasi dan mengapload informasi, sehingga proses pembelajaran semakin efektif dan efisien. Implikasinya akan mempercpat proses peningkatan ilmu pengetahuan sekaligus mendukung tercapainya misi dakwah. 


\section{DAFTAR PUSTAKA}

\section{A. Referensi Cetak}

Gibson, Rowan. 1997. Rethinking The Future, London: Nicholas Brealy Publishing.

Pandapotan, Sianipar. 1996.Panduan Menggunakan Internet, Jakarta : Elex Media Computindo, Kelompok Gramedia.

Rose, Collin and Nicholl, Malcolm J. 1997.Accellerated Learning For The21st Century, New York : A Dell Trade Paperback.

Sasono, Adi. 2000. Pendidikan dan Teknologi Kerakyatan, Makalah disampaikan di dalam Kovensi Nasional Pendidikan Indonesia, UNJ: Jakarta.

Turney, C et.all. 1992.The School Manager : Educational Management Roles and Tasks, NSW Australia : Allen \& Unwin.

Wahab, Azis.2000. Pengelolaan Berbasis Sekolah, Makalah disampaikan di dalam Konvensi Nasional Pendidikan Indonesia, UNJ: Jakarta.

Dokumen :

http://www.whitehouse.gov/WH/EOP/edtech/index-source. http://members.tripod.com/ homelessness/education. 